\title{
Analysis of efficiency of phosphates sorption by different granulation of selected reactive material
}

\author{
Magda Kasprzyk ${ }^{1, *}$, Jarosław Węgler ${ }^{1}$, and Magdalena Gajewska ${ }^{1}$ \\ ${ }^{1}$ Faculty of Civil and Environmental Engineering, Gdansk University of Technology, Poland
}

\begin{abstract}
In the light of the need to find an effective way to remove phosphorus from wastewater, studies on the suitability of sorption materials in this process should be conducted. The aim of the study was to examine the potential benefits of using selected adsorbents to reduce orthophosphates from the model solution under steady conditions. The study was conducted on a laboratory scale using synthetic wastewater with concentration of $\mathrm{P}_{-} \mathrm{PO}_{4}$ in the range of $5-100 \mathrm{mg} / \mathrm{dm} 3$. Experiment has shown that fine-grained material M1 $(0-2 \mathrm{~mm})$ is highly effective at removal of phosphorus compounds at the level of $97.8 \%$ at the highest concentration of $\mathrm{P}_{-} \mathrm{PO}_{4}$. The sorption capacity achieved during the investigation was $9.6 \mathrm{mg} / \mathrm{g}$, while the maximum sorption capacity from the Langmuir model could reach up to $256 \mathrm{mg} / \mathrm{g}$. Material M2 $(2-8 \mathrm{~mm}$ ) did not show satisfactory sorption capacity (maximum calculated sorption capacity: $0.36 \mathrm{mg} / \mathrm{g}$ ) and the effectiveness of phosphate reduction did not exceeded $6 \%$ at the lowest concentration of $\mathrm{P}-\mathrm{PO}_{4}$.
\end{abstract}

\section{Introduction}

Phosphorus, as a nutrient element, together with the nitrogen compounds enable plants growth. However, these processes require a small amount of nutrients. Their excess is the cause of eutrophication and algae bloom. Phosphorus compounds originate mainly from wastewater discharged into the lakes and other water bodies [1].

The removal of nutrients from wastewater is one of the basic problems of wastewater treatment plants. Most often their level is reduced in biological processes (using phosphorus as a source of energy for microorganisms) and chemical processes (reducing phosphate by salts of ferric or aluminum) of wastewater treatment [2].

Wastewater containing significant amounts of phosphorus compounds may originate both from large wastewater treatment plants and from smaller rural or domestic wastewater treatment plants. Most often the small wastewater treatment plants may discharge to the receivers wastewater purified insufficiently. The solution may be the use of filtration materials in domestic wastewater treatment plants and constructed wetlands [3, 4].

In recent years, the subject of research in terms of effectiveness are sorption materials (adsorbents) capable to bind significant amounts of phosphorus compounds. The source of their origin can be natural and anthropogenic. They may consist of silicon, calcium, aluminum, sulfur, iron in various weight ratio [5-12].

Unfortunately, the research methodology for evaluating the effectiveness of adsorbents in process of wastewater treatment is still under discussion. The lack of standardization the guidelines is a cause of difficulties in comparing different materials and their application in practice. In accessible research papers can be found methods differ in the concentration of the model solution, the volume, the amount of added sorption material, way and mixing time of the sample and the time of contact adsorbent with the model solution. Therefore, the scope of the differences in research methodology is significant $[1,13]$.

The aim of this study was an evaluation of selected sorption material in two fractions to compare the influence of grain size on phosphorus removal efficiency from wastewater in steady conditions. Another purpose was the determination of parameters of the Langmuir and Freundlich adsorption isotherms and maximum sorption capacity.

\section{Materials and methods}

\subsection{Materials}
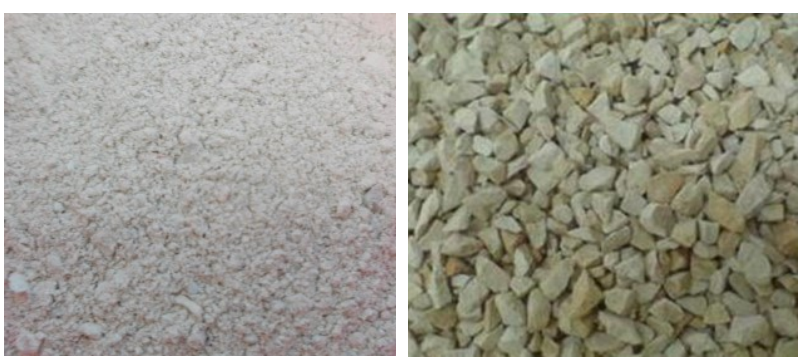

Fig. 1. Material M1 - 0-2 mm (on the left), material M2 - 2-8 $\mathrm{mm}$ (on the right).

\footnotetext{
* Corresponding author: magkaspr@pg.edu.pl
} 
Material M1 (Fig.1) is a fine-grained $(0-2 \mathrm{~mm})$ product of thermal treatment of carbonate-siliceous rock with high content of calcium carbonate $\mathrm{CaCO}_{3}$ in temperature $700^{\circ} \mathrm{C}$. This fraction if by-product of the $\mathrm{M} 2$ material and due to very fine-grain consisting mostly a calcium oxide $\mathrm{CaO}$ (above $80 \%$ ).

Material M2 is produced in process of decarbonization of natural carbonate-siliceous rock (opoka) (Fig.1). Because of high content of elements like calcium, silicon and aluminum, material M2 presents abilities to bind phosphorus compounds from wastewater. Material M2 is also known under the name ROCKFOS $^{\circledR}$. The only Polish producer of Rockfos ${ }^{\circledR}$ is Ceramika KUFEL from Suchynia.

Calcium oxide $\mathrm{CaO}$ and silicon oxide $\mathrm{SiO}_{2}$ present in the Rockfos $^{\circledR}$ chemical composition in the highest concentration (Table 1).

Table 1. Chemical composition of Rockfos ${ }^{\circledR}$ [20].

\begin{tabular}{|c|c|}
\hline Chemical composition & Concentration \\
\hline $\mathrm{CaO}$ & $43.3 \%$ \\
\hline $\mathrm{SiO}_{2}$ & $36.0 \%$ \\
\hline $\mathrm{Al}_{2} \mathrm{O}_{3}$ & $5.9 \%$ \\
\hline $\mathrm{Na}_{2} \mathrm{O}$ & $2.9 \%$ \\
\hline $\mathrm{Fe}$ & $1.3 \%$ \\
\hline $\mathrm{TiO}_{3}$ & $0.96 \%$ \\
\hline $\mathrm{MgO}$ & $0.94 \%$ \\
\hline $\mathrm{S}$ & $0.65 \%$ \\
\hline$\sum \mathrm{K}_{2} \mathrm{O}, \mathrm{P}, \mathrm{Cl}, \mathrm{MnO}$ & $\sim 2 \%$ \\
\hline
\end{tabular}

Porosity of $\operatorname{Rockfos}^{\circledR}$ is over $50 \%$ and size of particles is around $2-8 \mathrm{~mm}$. Disadvantage of this material may be particularly high level of $\mathrm{pH}$ (11-12), which results in alkaline solution (Table 2).

Table 2. Physical characteristic of Rockfos ${ }^{\circledR}[20]$.

\begin{tabular}{|c|c|}
\hline Physical properties & Value \\
\hline Average particle size $(\mathrm{mm})$ & $2-8$ \\
\hline Porosity $(\%)$ & $\sim 50$ \\
\hline $\mathrm{pH}$ & $11-12$ \\
\hline
\end{tabular}

\subsection{Experiment design}

To carry out the laboratory investigation, portions of $10 \mathrm{~g}$ of each selected materials was prepared. In order to determine the adsorption isotherms of these materials model solution was used. The model solution was prepared from distilled water and a solution of potassium dihydrogen phosphate $\mathrm{KH}_{2} \mathrm{PO}_{4}\left(1 \mathrm{~cm}^{3}-10 \mathrm{mgPO}_{4} / \mathrm{dm}^{3}\right)$. In each of the 5 batch reactors, there was a model solution in a volume of $1.0 \mathrm{dm}^{3}$ with a phosphate phosphorus concentration of $5-100 \mathrm{mg} / \mathrm{dm}^{3}$ (Table 3).

To each of the 5 batch reactors, $10 \mathrm{~g}$ of selected material was added. Mixing time lasted 5 minutes and was provided by magnetic stirrer $(1000 \mathrm{rpm})$. Samples were collected after 1 hour of sedimentation. Three series of repetitions were made for each material. All tests were performed at room temperature of approximately $20^{\circ} \mathrm{C}$.

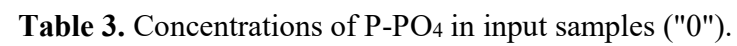

\begin{tabular}{|c|c|c|c|c|c|c|}
\hline \multicolumn{2}{|c|}{ Batch reactor } & 1 & 2 & 3 & 4 & 5 \\
\hline \multicolumn{2}{|c|}{$\begin{array}{c}\begin{array}{c}\text { Assumed initial } \\
\text { concentration } \\
{\left[\mathrm{mg} / \mathbf{d m}^{3}\right]}\end{array} \\
\end{array}$} & 5.0 & 10.0 & 20.0 & 50.0 & 100.0 \\
\hline \multirow{2}{*}{$\begin{array}{c}\text { Average real } \\
\text { concentration } \\
{\left[\mathbf{m g} / \mathbf{d m}^{3}\right]}\end{array}$} & M1 & 5.11 & 9.94 & 19.6 & 48.1 & 97.3 \\
\hline & M2 & 5.11 & 10.05 & 19.6 & 47.9 & 96.0 \\
\hline
\end{tabular}

\subsection{Physical and chemical analysis}

Before the designation of the concentration of $\mathrm{P}_{-} \mathrm{PO}_{4}$ of synthetic wastewater, the samples were subjected to filtration. The concentration of the phosphorus phosphate was marked by using the cuvette tests $\mathrm{HACH}$ Lange and HACH Lange DR 3900 laboratory VIS spectrophotometer with RFID.

On the basis of the obtained results, the series of analyses were conducted in order to verify the suitability of selected materials for removing phosphorus compounds by adsorption. The effectiveness of binding $\mathrm{P}^{-} \mathrm{PO}_{4}$ by selected materials was calculated by equation (1) $[13]$ :

$$
E=\left(C_{0}-C\right) / C_{0} \cdot 100 \%
$$

where: $E$ - effectiveness of phosphorus removal [\%], $C_{0}$ - initial concentration of $\mathrm{P}^{-\mathrm{PO}_{4}}$ in model solution $\left[\mathrm{mg} / \mathrm{dm}^{3}\right] ; C$ - final concentration of $\mathrm{P}_{-} \mathrm{PO}_{4}$ in model solution $\left[\mathrm{mg} / \mathrm{dm}^{3}\right]$.

Quantity of adsorbed amount of phosphorus compounds from model solution was designated according to formula (2) [12, 14]:

$$
q=\left(C_{0}-C\right) \cdot V / m
$$

where: $q$ - quantity of adsorbed $\mathrm{P}^{-\mathrm{PO}_{4}}$ from model solution $[\mathrm{mg} / \mathrm{g}], V$ - volume of model solution $\left[\mathrm{dm}^{3}\right]$, $C_{0}$ - initial concentration of $\mathrm{P}_{-} \mathrm{PO}_{4}$ in model solution $\left[\mathrm{mg} / \mathrm{dm}^{3}\right] ; C$ - final concentration of $\mathrm{P}^{-\mathrm{PO}_{4}}$ in model solution $\left[\mathrm{mg} / \mathrm{dm}^{3}\right], m$ - mass of sorption material $[\mathrm{g}]$.

\subsection{Adsorption models}

Sorption capacity was analyzed on the basis of the relation between the quantity of adsorbed phosphorus by sorption material $q_{e}[\mathrm{mg} / \mathrm{g}]$ and equilibrium concentration $C_{e}\left[\mathrm{mg} / \mathrm{dm}^{3}\right]$. This relation is described by mathematical equations of adsorption isotherms. Parameters of the adsorption isotherms of selected materials were determined based on model given by [13,15-18]:

a) Langmuir

$$
q_{e}=\left(K_{L} \cdot C_{e}\right) /\left(1+a_{l} \cdot C_{e}\right)
$$

where: $q_{e}-$ sorption capacity $[\mathrm{mg} / \mathrm{g}] ; a_{l} .\left[\mathrm{dm}^{3} / \mathrm{mg}\right]$, $K_{L}\left[\mathrm{dm}^{3} / \mathrm{g}\right]$ - constant parameters in Langmuir model of adsorption; $C_{e}-$ concentration of $\mathrm{P}^{-\mathrm{PO}_{4}}$ at equilibrium 
$\left[\mathrm{mg} / \mathrm{dm}^{3}\right], K_{L} / a_{l .}=q_{\max }-$ maximum sorption capacity $[\mathrm{mg} / \mathrm{g}]$. Equation (3) in linear form becomes:

$$
1 / q_{e}=1 / K_{L} \cdot 1 / C_{e}+a_{L} / K_{L}
$$

b) Freundlich

$$
q_{e}=a_{F} \cdot C_{e}^{b F}
$$

where: $q_{e}-$ sorption capacity $[\mathrm{mg} / \mathrm{g}] ; C_{e}-$ concentration of $\mathrm{P}_{-} \mathrm{PO}_{4}$ at equilibrium $\left[\mathrm{mg} / \mathrm{dm}^{3}\right] ; a_{F}\left[\mathrm{dm}^{3} / \mathrm{g}\right]$, $b_{F}\left[\mathrm{dm}^{3} / \mathrm{mg}\right]$ - constant parameters in Freundlich model of adsorption. Equation (5) in linear form becomes:

$$
\log q_{e}=\log a_{F}+b_{F} \cdot \log C_{e}
$$

Graphical interpretation of linear equations (4) and (6) are shown in figures $2-5$, where adsorption isotherms are presented in form (7):

$$
y=a \cdot x+b
$$

where:

for Langmuir isotherm:

$y=1 / q_{e} \quad x=1 / C_{e} \quad a=1 / K_{L} b=a_{L} / K_{L}$

for Freundlich isotherm:

$y=\log q_{e} \quad x=\log C_{e} \quad a=b_{F} \quad b=\log a_{F}$

\section{Results and discussion}

The basic parameters $(q, E)$ to evaluate the efficiency of phosphorus removal from synthetic wastewater of two selected materials are presented in Table 4.

Table 4. Sorption capacity and effectiveness of phosphorus removal.

\begin{tabular}{|c|c|c|c|}
\hline \multicolumn{5}{|c|}{ M1 } \\
\hline $\boldsymbol{C}_{\boldsymbol{o}}\left[\mathbf{m g} / \mathbf{d m}^{\mathbf{3}}\right]$ & $\boldsymbol{C}\left[\mathbf{m g} / \mathbf{d m}^{\mathbf{3}}\right]$ & $\boldsymbol{q}[\mathbf{m g} / \mathbf{g}]$ & $\boldsymbol{E}[\mathbf{\%}]$ \\
\hline 5.11 & 0.27 & 0.49 & 94.8 \\
\hline 9.94 & 0.53 & 0.94 & 94.7 \\
\hline 19.6 & 0.9 & 1.9 & 95.4 \\
\hline 48.1 & 1.5 & 4.7 & 97.0 \\
\hline 97.3 & 2.1 & 9.6 & 97.8 \\
\hline \multicolumn{4}{|c|}{$\mathbf{M} \mathbf{2}$} \\
\hline $\boldsymbol{C}_{\boldsymbol{0}}\left[\mathbf{m g} / \mathbf{d m}^{3}\right]$ & $\boldsymbol{C}\left[\mathbf{m g} / \mathbf{d m}^{3}\right]$ & $\boldsymbol{q}[\mathbf{m g} / \mathbf{g}]$ & $\boldsymbol{E}[\mathbf{\%}]$ \\
\hline 5.11 & 4.90 & 0.03 & 6.0 \\
\hline 10.05 & 9.52 & 0.05 & 5.3 \\
\hline 19.6 & 18.6 & 0.1 & 5.4 \\
\hline 47.9 & 46.5 & 0.1 & 2.9 \\
\hline 96.0 & 93.0 & 0.3 & 3.1 \\
\hline
\end{tabular}

For material M1 efficiency of phosphorus reduction and sorption capacity increased with the increase of initial concentration of $\mathrm{P}_{-} \mathrm{PO}_{4}$. At the highest concentration of $\mathrm{P}_{-} \mathrm{PO}_{4}$ sorption capacity reached $9.6 \mathrm{mg} / \mathrm{g}$, and the level of reduction of phosphorus compounds was nearly $98 \%$. Similar results also for fine-grain particles (1-2 $\mathrm{mm})$ were occurred for carbonate-siliceous rock (opoka) heated in temperature $900{ }^{\circ} \mathrm{C}$. Efficiency of phosphorus removal reached to $97 \%$ [2]. Those study was proceeded with flow conditions in models of filters with vertical flow.

Material M2 showed much lower efficiency of $\mathrm{P}_{-} \mathrm{PO}_{4}$ removal, which decreased along with increasing initial concentration. For the lowest concentration $\left(5.11 \mathrm{mg} / \mathrm{dm}^{3}\right)$, the effectiveness of binding phosphates by sorption material was only $6 \%$, while maximum sorption capacity at the highest concentration was equal to $0.3 \mathrm{mg} / \mathrm{g}$.

Graphical analysis of the results of laboratory investigation showed good matching for both Langmuir and Freundlich isotherms of adsorption to describe the sorption process for both sorption materials (Fig. 3-6). The coefficient of determination for Langmuir isotherm was equal to 0.99 , and for Freundlich isotherm was about 0.97 (Table 5). The linear correlation coefficient was obtain on the level of $\mathrm{r}=0.996$ for Langmuir isotherm and $r=0.985$ for Freundlich isotherm.

Maximum sorption capacity of analyzed materials was obtained from parameters of Langmuir isotherm and equal $294.12 \mathrm{mg} / \mathrm{g}$ for material $\mathrm{M} 1$, and $0.36 \mathrm{mg} / \mathrm{g}$ for material M2. Sorption capacity of both materials is

\begin{tabular}{|c|c|c|c|c|}
\hline \multicolumn{5}{|c|}{ Langmuir isotherm } \\
\hline & $K_{L}\left[\mathrm{dm}^{3} / \mathrm{g}\right]$ & $a_{L}\left[\mathrm{dm}^{3} / \mathrm{mg}\right]$ & $q_{\max }[\mathrm{mg} / \mathrm{g}]$ & $\mathbf{R}^{2}$ \\
\hline M1 & 2.1598 & 0.0084 & 256.41 & 0.991 \\
\hline M2 & 0.0070 & 0.0191 & 0.36 & 0.990 \\
\hline \multicolumn{5}{|c|}{ Freundlich isotherm } \\
\hline & $a_{F}\left[\mathrm{dm}^{3} / \mathrm{g}\right]$ & $b_{F}\left[\mathrm{dm}^{3} / \mathrm{mg}\right]$ & $\mathbf{R}^{2}$ & \\
\hline M1 & 2.8438 & 1.3358 & 0.968 & \\
\hline M2 & 0.0104 & 0.7276 & 0.972 & \\
\hline
\end{tabular}
incomparable (Table 5).

Table 5. Parameters of the Langmuir and Freundlich adsorption isotherms of materials M1 and M2.

Comparing the results of current laboratory investigation, material M1 has shown one of the higher sorption capacity. Similar results were obtained in the studies presented in [12], where the sorption material was composed mostly of calcium oxide $(70 \%)$, reached maximum sorption capacity over $285 \mathrm{mg} / \mathrm{g}$. Material composed of calcium sulfate, magnesium and iron compounds obtained $q_{\max }$ close to $160 \mathrm{mg} / \mathrm{g}$. Methodology of the research was different from that presented in this paper, as contact time, which lasted 24 hours. According to [6] the highest sorption capacity was achieved for Polonite ${ }^{\circledR}(94.32 \mathrm{mg} / \mathrm{g})$, but in this case, contact time was only 15 minutes.

Also very high sorption capacity was achieved in the experiment described in [19] at the level of $182 \mathrm{mg} / \mathrm{g}$. The contact time was also 1 hour. Examined materials were different types of opoka heated/treated in temperature $900{ }^{\circ} \mathrm{C}$. The highest sorption capacity was received for opoka with the highest calcium content $(420 \mathrm{~g} / \mathrm{kg})$. In process of high temperature treatment the conversion of calcium carbonate to calcium oxide 
occurred and released of carbon dioxide. Increased concentration of calcium oxide was causing the increase of sorption capacity. Also, $\mathrm{pH}$ of opoka was rising from 6.8 to over 12. In article [8] various types of heated opoka were analyzed. Obtained results of sorption

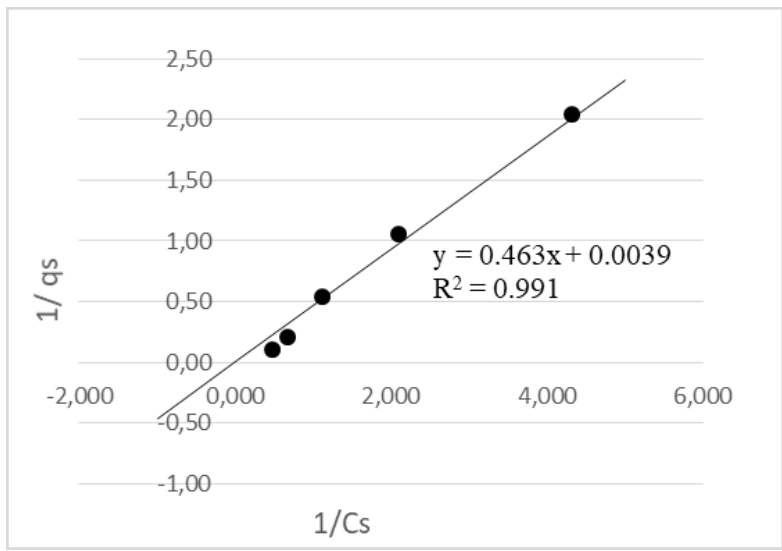

Fig.2. Langmuir isotherm of material M1.

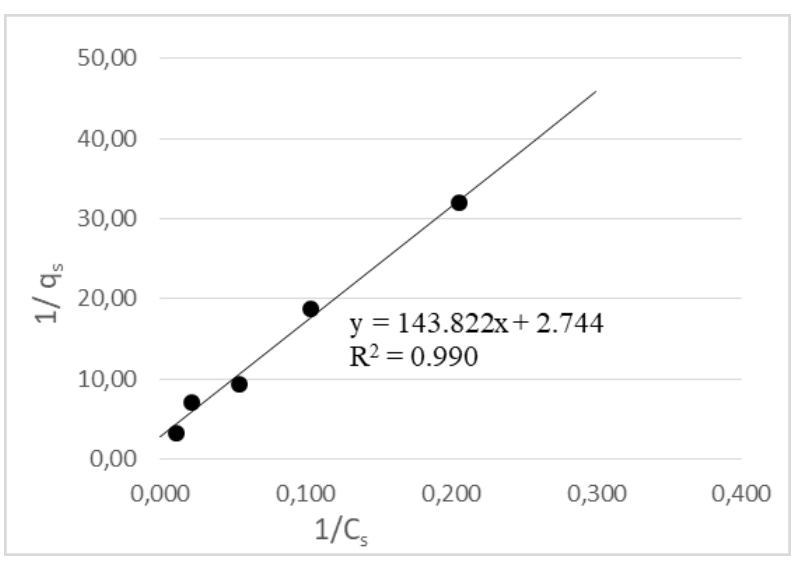

Fig.3. Langmuir isotherm of material M2.

\section{Conclusions}

Based on obtained results and their evaluation, following statements could be concluded:

1. The achieved results confirmed the influence of both grain size of the sorption material as well as the conditions (flow or stable) for removal efficiency.

2. In stable condition, the material M2 was ineffective (maximum sorption capacity was only $0.36 \mathrm{mg} / \mathrm{g}$ ) and can be considered as unsuitable for the removal of phosphorus from wastewater in such conditions.

3. Material M1 has shown substantial ability to remove phosphorus compounds (256.4 mg/g) and also was highly effective in adsorption process - 97.8\%. Preliminary analysis allows to apply this material in further studies. Also because of the high content of calcium oxide, those studies should consider the influence of material over $\mathrm{pH}$ changes.

4. Investigation has confirmed the influence of content of calcium oxide and size of the particles over achieved sorption capacity level. With the higher content of $\mathrm{CaO}$ and smaller size of the particles, sorption capacity is increasing. capacity were around $12-25 \mathrm{mg} / \mathrm{g}$ with short contact time which lasts - 15 minutes. Again the best results were received for opoka with the highest content of $\mathrm{CaO}$ $(520.1 \mathrm{~g} / \mathrm{kg})$.

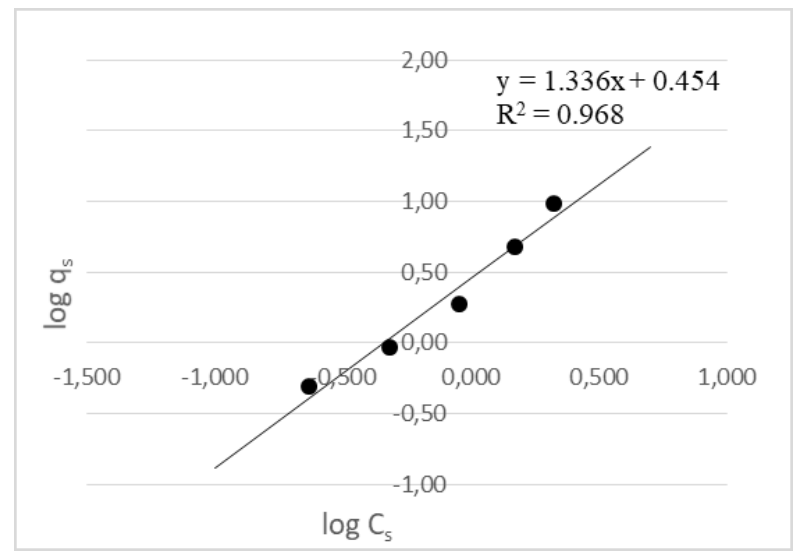

Fig.4. Freundlich isotherm of material M1.

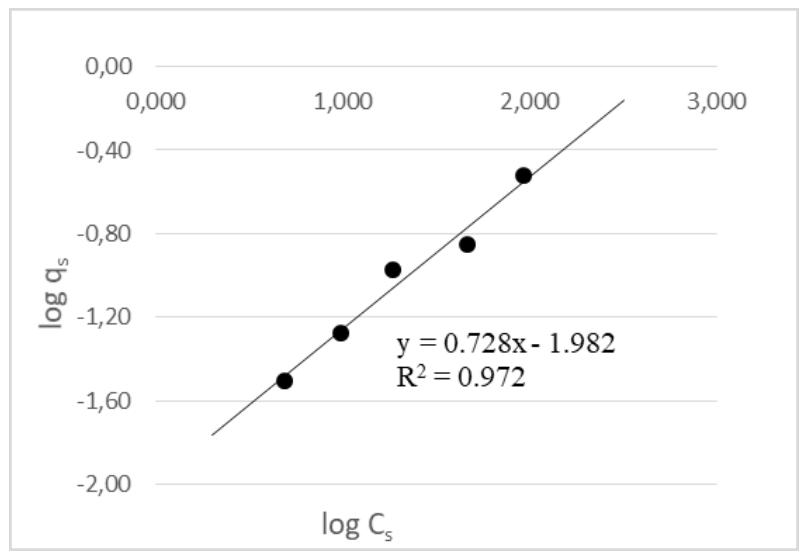

Fig.5. Freundlich isotherm of material M2.

5. Used mathematical models of adsorption (Langmuir and Freundlich) has shown well matching of isotherms for graphical analysis of received results $\left(\mathrm{R}^{2}=0.97-0.99\right)$.

6. There is a need to test the applicability of M2 material in flow conditions for phosphorus removal.

7. Also there is a necessity to standardize methodology to determine the sorption capacity of materials used in various experiments. They should describe the way of evaluation suitability to remove phosphorous compounds from wastewater.

The research is carried out within the subtask 2.3 of the project entitled "Integrated technology for improved energy balance and reduced greenhouse gas emissions at municipal wastewater treatment plants" with the acronym "BARITECH" co-funded by the Norwegian funds, under the PolishNorwegian Cooperation Research carried out by the National Centre for Research and Development [197025/37/2013].

Special thanks to Polish producer of Rockfos ${ }^{\circledR}$, Ceramika KUFEL from Suchynia for the free of charge sharing of research material. 


\section{References}

1. L. Johansson Westholm, Water Research $\mathbf{4 0}$ (1), 23 (2006)

2. K. Jóźwiakowski, M. Gajewska, A. Pytka, M. Marzec, M. Gizińska-Górna, A. Jucherski, A. Walczowski, M. Nastawny, A. Kamińska, S. Baran, Ecological Engineering 98, 290 (2017)

3. A. Jucherski, M. Nastawny, A. Walczowski, K. Jóźwiakowski, M. Gajewska, Ochrona Środowiska 39 (1), 33 (2017)

4. H. Brix, C.A. Arias, M Del Bubba, Water Science and Technology 44 (11-12), 47 (2001)

5. G. Renman, A. Renman, WASCON 2012 Conference proceedings (2012)

6. A. Karczmarczyk, A. Bus, Annals Of Warsaw University Of Life Sciences - SGGW. Land Reclamation 46 (1), 57 (2014)

7. A. Bus, A. Karczmarczyk, A. Baryła, Inzynieria Ekologiczna 39, 33 (2014)

8. A. Bus, A. Karczmarczyk, Infrastruktura i Ekologia Terenów Wiejskich II/1, 227 (2014)

9. C. Vohla., M. Kõiv, H.J. Bavor, F. Chazarenc, Ü. Mander, Ecological Engineering 37, 70 (2011)

10. A. Karczmarczyk, A. Bus, A. Baryła, Ecological Engineering 86, 69 (2016)

11. A. Renman, On-site wastewaters treatment Polonite and other filter materials for removal of metals, nitrogen and phosphorus (TRITA-LWR $\mathrm{PhD}$ Thesis 1043, KTH Royal Institute of Technology, 2008)

12. M. Nastawny, A. Jucherski, A. Walczowski, K. Jóźwiakowski, A. Pytka, M. Gizińska-Górna, M. Marzec, M. Gajewska, A. Marczuk, J. Zarajczyk, Przemysł Chemiczny 94 (10), 1001 (2015)

13. A. Bus, A. Karczmarczyk, Fresenius Environmental Bulletin 24 (9), 2736 (2015)

14. X. Liu, L. Zhang, Powder Technology 277, $112(2015)$

15. V. Cucarella, G. Renman, J. Environ. Qual. 38, 381 (2009)

16. M. Del Bubba, C.A. Arias, H. Brix, Water Research 37 (14), 3390 (2003)

17. Z. Xu, Jian-Guo Cai, Bing-Cai Pan, Journal of Zhejiang University-SCIENCE A, Applied Physics \& Engineering 14 (3), 155 (2013)

18. G.Limousin, J.P. Gaudet, L. Charlet, S. Szenknect, V. Barthea, M. Krimissa, Applied Geochemistry 22, 249 (2007)

19. V. Cucarella, T. Zaleski, R. Mazurek: Annals of Warsaw University of Life Sciences - SGGW. Land Reclamation 38, 11 (2007)

20. Product Data Sheet of Rockfos ${ }^{\mathbb{B}}$ 